\title{
Exchange fairness and employee performance: An examination of the relationship between organizational politics and procedural justice
}

\author{
Samuel Aryee, ${ }^{\mathrm{a}, *}$ Zhen Xiong Chen, ${ }^{\mathrm{b}, 1}$ and Pawan S. Budhwar ${ }^{\mathrm{c}, 2}$ \\ a Department of Management, Hong Kong Baptist University, 34 Renfrew Road, Kowloon Tong, Hong Kong \\ ${ }^{\mathrm{b}}$ School of Business and Government, University of Canberra, ACT 2601, Australia \\ ${ }^{\mathrm{c}}$ Aston Business School, Aston University, Birmingham, B4 7ET, UK
}

\begin{abstract}
Data obtained from a manufacturing firm and a newspaper firm in India were used to examine the relationship between organizational politics and procedural justice in three separate studies. Study 1 constructively replicated research on the distinctiveness of the two constructs. Confirmatory factor analyses in which data from the manufacturing firm served as the development sample and data from the newspaper firm served as the validation sample demonstrated the distinctiveness of organizational politics and procedural justice. Study 2 examined the antecedents of the two constructs using data from the manufacturing firm. Structural equation modeling (SEM) results revealed formalization and participation in decision making to be positively related to procedural justice but negatively related to organizational politics. Further, authority hierarchy and spatial distance were positively related to organizational politics but unrelated to procedural justice. Study 3 examined the consequences of the two constructs in terms of task and contextual performance using data from the newspaper firm. Results of SEM analysis revealed procedural justice but not organizational politics to be related to task performance and the contextual performance dimensions of interpersonal facilitation and job dedication.
\end{abstract}

(c) 2004 Elsevier Inc. All rights reserved.

Inherent in the conceptualization of an employment relationship as one of exchange, is the view of an organization as a marketplace where employees invest or exchange resources such as talent and effort, in return for tangible (e.g., pay) and intangible (e.g., self-esteem) organizational rewards. For example, Cropanzano and his associates (Cropanzano, Howes, Grandey, \& Toth, 1997; Randall, Cropanzano, Bormann, \& Birjulin, 1999) noted that a workplace can be conceptualized as a social marketplace in which multiple individuals engage in several transactions each seeking to obtain a favorable return on their investment. The possibility of receiving a favorable return on one's investment is contingent,

\footnotetext{
${ }^{*}$ Corresponding author. Fax: +852-233-95583.

E-mail addresses: saryee@hkbu.edu.hk (S. Aryee), George.Chen@ canberra.edu.au (Z.X. Chen), P.S.budhwar@aston.ac.uk (P.S. Budhwar).

${ }^{1}$ Fax: +612-6201-5238.

${ }^{2}$ Fax: $+44121-359-2919$
}

among other factors, on the extent to which organizational rewards are perceived to be fairly allocated. Two constructs which are germane to the allocative process are perceptions of organizational politics and organizational justice particularly, procedural justice. ${ }^{3}$

As a perceptual phenomenon, organizational politics "involves an individual's attribution of self-serving intent, and is defined as an individual's subjective evaluation about the extent to which the work environment is characterized by coworkers and supervisors who demonstrate such self-serving behavior" (Ferris, HarrellCook, \& Dulebohn, 2000, p. 90). Organizational politics

\footnotetext{
${ }^{3}$ We chose to focus on procedural or structural justice rather than interactional or distributive justice because previous research suggests that procedural justice is especially relevant to events at the organizational level (Masterson, Lewis, Goldman, \& Taylor, 2000). Furthermore, our concern to examine structural characteristics that promote perceptions of fairness in employee-organization exchanges is consistent with the focus of procedural justice on an organization's formalized system of rules and guidelines.
} 
may, therefore, stem from informal behaviors which are not sanctioned by the organization but which are designed to promote the goals of an individual. In contrast, organizational justice describes "the ways in which employees determine if they have been treated fairly in their jobs and the ways in which these determinations influence other work-related variables" (Moorman, 1991, p. 845). As a dimension of organizational justice, procedural justice describes the fairness of procedures used in the allocation process (Folger \& Greenberg, 1985; Tyler \& Lind, 1992). Although organizational politics and procedural justice have been noted to be inextricably intertwined (Ambrose \& Harland, 1995), unlike procedural justice, the negative consequences of organizational politics have been shown to be ameliorated by the requisite coping skills (Ferris et al., 1993) and demographic group membership (Ferris, Frink, Bhawuk, Zhou, \& Gilmore, 1996).

The two constructs have empirically been shown to be related to myriad organizational outcomes including performance (Cropanzano et al., 1997; Ferris, Adams, Kolodinsky, Hochwarter, \& Ammeter, 2002; Kacmar \& Baron, 1999; Randall et al., 1999). The demonstrated outcomes of organizational politics and procedural justice coupled with the fact that they are underpinned by the theme of fairness, have precipitated interest in the extent to which they are conceptually distinct (Andrews $\&$ Kacmar, 2001). The importance of the fairness of employee exchanges with the organization makes it necessary to understand the extent to which constructs that are central to these exchanges are conceptually distinct. This is particularly so, in view of the fact that fairness of employee-organization exchanges has been employed as a framework to explain the motivational underpinning of employee performance (Podsakoff, MacKenzie, Paine, \& Bachrach, 2000). Given the implication of organizational politics and procedural justice for the fairness of employee-organization exchanges and the evidence linking the two constructs to performance, it is unfortunate that research has not yet examined how they combine to influence employee performance. Understanding employee performance is a particularly important undertaking given that discretionary performance has been noted to be critical to organizational effectiveness in an increasingly competitive marketplace (Katz, 1964; Podsakoff et al., 2000). The preceding discussion highlights two research questions: (i) Are organizational politics and procedural justice distinct constructs? and (ii) How do these constructs combine to influence employee performance? Data obtained from two organizations in India were used to address these questions.

In spite of the recognition that politics perception is inherent in organizational life and the universality of concerns about fairness (Morris \& Leung, 2000; Pearce, Bigley, \& Branyiczki, 1998), much of the extant research (particularly on organizational politics) has focused on Western, specifically North American samples. Thus, the extent to which findings in the literature generalize to nonWestern contexts is an important question which has not been adequately addressed. Pearce and her associates' (Pearce, 2001; Pearce, Branyiczki, \& Bigley, 2000) distinction between facilitative and nonfacilitative contexts is a particularly useful one when considered in the context of fairness in employee-organization exchanges. Their distinction is based on the extent to which major social institutions such as governments and businesses enforce the rule of law in Weber's (1947) rational legal sense.

Following Wade (1981), Pearce (2001) described India as a nonfacilitative organizational context. While organizations in India have adopted bureaucracy, the person-oriented nature of Indian society suggests an emphasis on particularistic rather than universalistic treatment of employees. Pearce et al. (2000, p. 150) noted that in "...... particularistic settings, those with power to hire, reward and fire would be expected to do so based on certain employee's personal characteristics." Emphasis on particularism suggests that although bureaucratic means of formalism and hierarchy are present, they have been harnessed to particularistic ends leading to perceptions of lack of fairness in employee-organization exchanges. Relatedly, Pandey (1986) noted that manipulative behaviors that have implications for fairness of employee-organization exchanges are more prevalent in developing countries characterized as they are, by resource scarcity, inequality, deprivation, and sociopolitical uncertainty. Given that much of the extant research has been conducted in the facilitative organizational context of North America, the question arises as to whether the factors that shape perceptions of fairness in employeeorganization exchanges are similar or differ in the context of a particularistic, developing country such as India. Globalization and the resulting need to manage a multi-cultural workforce suggest a practical concern in understanding how employees in different cultural contexts perceive fairness in employee-organization exchanges and the implications of such perceptions for their job performance.

\section{Examining the distinctiveness of organizational politics and procedural justice}

We sought to establish the distinctiveness of organizational politics and procedural justice by examining their relationship and antecedents. In this section, we provide a brief discussion of the two constructs followed by a review of the literature, and a formal statement of the hypotheses linking the antecedents to the two constructs. 


\section{Organizational politics}

To facilitate a programmatic research on organizational politics, Ferris, Russ, and Fandt (1989) identified two streams of research: (a) the nature of actual political behavior, types of tactics and strategies, and their consequences and (b) perceptions of politics in work environments by individual employees, the antecedents of such perceptions and their consequences. Although these two streams of research are implicitly interrelated, it is only in recent times that research has examined how perceptions of politics and political behavior might be interrelated (Ferris et al., 2000; Harrell-Cook, Ferris, \& Dulebohn, 1999). Our focus in this study is on perceptions of politics in work environments. Examining perceptions of politics is important because as Gandz and Murray (1980) suggest, organizational politics ought to be conceived of as a subjective evaluation rather than an objective state. This is because it is the cognitive evaluation of perceptions of events that influence people's reactions and the outcomes of those reactions (Lewin, 1936).

As a means of getting things done in organizations, a mechanism for resolving conflicts outside of the formal bureaucratic structure (Morgan, 1996; Pfeffer, 1992), politics may have positive consequences. However, politics is generally viewed as a potentially negative activity. This is because research evidence indicates that when asked to describe political behavior, respondents typically list self-serving and manipulative activities that are negatively evaluated (Drory \& Romm, 1988; Gandz \& Murray, 1980; Madison, Allen, Porter, Renwick, \& Mayes, 1980; Vigoda, 2001). From this perspective, politics is considered a self-serving interpersonal influence behavior, not formally sanctioned by the organization and designed to maximize self-interest at the expense of others (Mintzberg, 1985). Perceptions of politics may stem from informal behaviors which are not sanctioned by the organization but which are designed to promote the goals of the individual thereby creating an organizational politics climate.

\section{Procedural justice}

Operating within a structural framework, Leventhal and his associates' (Leventhal, 1980; Leventhal, Karuza, \& Fry, 1980) focus on reward allocation decisions extended the notion of procedural justice into nonlegal contexts such as organizational settings. They identified six procedural rules against which fairness of procedures may be evaluated. These rules are (a) consistency ruleallocation procedures should be consistent across persons and over time; (b) bias suppression rule-personal self-interest in the allocation process should be prevented; (c) accuracy rule - decisions must be based on accurate information; (d) correctability rule-opportu- nities must exist to enable decisions to be modified; (e) representativeness rule-the allocation process must represent the concerns of all recipients, and (f) ethicality rule -allocations must be based on prevailing moral and ethical standards. Procedural justice is, therefore, concerned primarily with the extent to which structural features of decision making (allocation process) facilitate employee voice, appropriateness of criteria, and the accuracy of the information used to arrive at a decisional outcome (Cropanzano, Prehar, \& Chen, 2002). To the extent these structural features minimize individual influence in the allocation process, they bear remarkable similarity to the "meritocratic principles of universalism and impersonal decision making that Weber (1947) associated with bureaucracy" (Pearce et al., 1998, p. 375).

\section{Antecedents of organizational politics and procedural justice}

Employee-organization exchanges take place within a social context and for that reason, some organizational structures may enhance the likelihood of fair exchanges than others. What then are the characteristics of organizations that promote fair and unfair exchanges? Sheppard, Lewicki, and Minton (1993) suggested that systemically fair organizations are characterized by participation and an emphasis on due process. This is consistent with Pearce and her associates' distinction between facilitative and nonfacilitative organizational contexts on the basis of the extent to which they promote the rule of law. While the implications of the organization's context on employee-organization exchanges has long informed research on the antecedents of perceptions of politics (Ferris et al., 2002; Kacmar \& Baron, 1999), it has only recently, informed research on the antecedents of procedural justice (Schminke, Ambrose, \& Cropanzano, 2000; Schminke, Cropanzano, \& Rupp, 2002). For example, Schminke et al. (2000, p. 301) noted that "as purposively constructed social systems, organizations provide the environmental context in which fair and unfair interactions inspire. To neglect structural attributes is to neglect the setting in which fair and unfair interactions inspire."

Although we recognize a multitude of antecedents of perceptions of organizational politics and procedural justice, we focused on structural antecedents because of their implications for the rule of law in organizational contexts. Antecedents examined in this study are formalization, centralization, and spatial distance. A limitation of the extant research on politics perceptions is the failure to address the issue of level of analysis, which may threaten statistical conclusion validity. Ferris et al. (2000, p. 215) noted that researchers have measured individuals' perceptions of formalization and centralization at the 
group level, which reduces these constructs to an individual's perception of group-level phenomena. Accordingly, we treated formalization and centralization as group-level variables.

\section{Formalization}

Formalization describes the extent to which organizations attempt to achieve uniformity and standardization in job behavior and system operation through rules, regulations, procedures, and policies (Pugh, Hickson, Hinings, \& Turner, 1968). Highly formalized structures should constrain individual discretion and facilitate the application of universalistic principles to the treatment of employees leading to perceptions of a within-organization 'rule of law.' Previous research has reported a positive relationship between formalization and procedural justice (Andrews \& Kacmar, 2001; Schminke et al., 2002). In contrast, formalization has been reported to be negatively related to perceptions of organizational politics (Andrews \& Kacmar, 2001; Ferris et al., 1996; Ferris \& Kacmar, 1992). This is because rules and procedures that promote consistent or universalistic treatment of employees in highly formalized structures eliminate uncertainty and opportunities for the particularistic treatment of employees, thereby minimizing perceptions of organizational politics.

Hypothesis 1. A higher level of formalization will be positively related to procedural justice but negatively related to perceptions of organizational politics.

\section{Centralization}

Centralization describes the extent to which decisionmaking authority is centralized in a single point in the organization. Following Schminke et al. (2000), we examined the two components of centralization identified by Hage and Aiken (1967). These are participation in decision making and authority hierarchy. Participation in decision making describes the relative concentration of decision-making power with regard to policy making such as issues relating to hiring, promotion, and formulating departmental policies. Authority hierarchy on the other hand, describes the relative concentration of decision-making power with regard to task performance or task-related autonomy. A low degree of participation in decision making and a high degree of authority hierarchy indicate a highly centralized structure. Schminke et al. (2000) reported participation in decisionmaking power to be positively related to procedural justice and authority hierarchy to be negatively related to procedural justice.

With the exception of Parker, Dipboye, and Jackson (1995) who reported a negative relationship between centralization and perceptions of organizational politics, a highly centralized structure has consistently been reported to be positively related to organizational politics (Andrews \& Kacmar, 2001; Ferris et al., 1996; Kacmar, Bozeman, Carlson, \& Anthony, 1999; Valle \& Perrewé, 2000). A low degree of participation in decision making (high centralization) will be positively related to perceptions of organizational politics. Lack of input into decision making in highly centralized structures reduces perceptions of control leading to increased levels of perceptions of organizational politics. Although as a component of a centralized structure, authority hierarchy has not been examined as an antecedent of organizational politics, task autonomy, a conceptually similar construct, has been shown to be negatively related to perceptions of organizational politics (Ferris \& Kacmar, 1992, Study 1). Task autonomy describes a reduced concentration of decision-making power with regard to performing tasks (Schminke et al., 2000, p. 296). The sense of personal control that stems from task autonomy should minimize perceptions of organizational politics.

Hypothesis 2a. Higher levels of participation in decision making (highly decentralized structure) will be positively related to procedural justice but negatively related to organizational politics.

Hypothesis 2b. Higher levels of authority hierarchy (highly centralized structure) will be negatively related to procedural justice but positively related to organizational politics.

\section{Spatial distance}

Spatial distance describes dyadic distance in the supervisor-subordinate relationship. It is reflected by a general perception of the amount of interaction on a day-to-day basis between a supervisor and a subordinate (Kerr \& Jermier, 1978; Napier \& Ferris, 1993). Spatial distance will be positively related to perceptions of organizational politics. This is because it will limit frequency of supervisor-subordinate interactions precipitating an inadequate understanding of the basis of supervisor decisions that affect subordinates. The uncertainty and ambiguity that such a situation engenders may be minimized by the subordinate's proactive use of supervisor-focused influence behaviors. Ferris, Judge, Rowland, and Fitzgibbons (1994), however, reported the effectiveness of supervisor-focused influence behaviors to be contingent on the subordinate's proximity to the supervisor. For subordinates in a spatially distant relationship with the supervisor, the ineffectiveness of such behaviors will exacerbate ambiguity and uncertainty in the organizational environment leading to perceptions of organizational politics. In contrast, we expect spatial distance to be unrelated to perceptions of 
procedural justice. This is because procedural justice facilitates the consistent treatment of employees regardless of spatial distance and by implication, frequency of supervisor-subordinate interactions. Based on the preceding discussion we hypothesized that:

Hypothesis 3. Spatial distance will be positively related to organizational politics but unrelated to procedural justice.

\section{Performance consequences of organizational politics and procedural justice}

Having theoretically demonstrated the distinctiveness of organizational politics and procedural justice in an Indian context, we then, sought to examine their consequences in terms of employee task and contextual performance. In this section, we provide a conceptual discussion of employee performance and a review of the literature relating these constructs to the outcome variables.

Recognition of employees as a competitive resource (Pfeffer, 1994) has given renewed impetus to organizational scholars' perennial interest in understanding employee behaviors particularly those that are discretionary but contribute to organizational effectiveness (Katz, 1964). This has become important in view of the uncertain and dynamic environments in which organizations operate making it difficult to specify behaviors that are needed or desired of employees. Campbell's (1990) proposition that job performance comprises not only tasks but interpersonal and motivational components has contributed to a better conceptualization of the performance construct. Researchers now distinguish between core tasks and contextual performance as two dimensions of employee performance (Borman \& Motowidlo, 1993; Conway, 1999; Motowidlo, Borman, \& Schmit, 1997; Van Scotter \& Motowidlo, 1996).

Task performance describes job-specific behaviors including core job responsibilities that are directly related to the organization's technical core. Contextual performance on the other hand, describes a set of interpersonal and volitional behaviors that support the social and motivational context in which organizational work is accomplished. It has been shown to have two facets-interpersonal facilitation and job dedication. Interpersonal facilitation describes interpersonally oriented behaviors that contribute to organizational goal accomplishment and include encouraging cooperation, consideration of others, and building and mending relationships. Job dedication on the other hand, describes 'self-disciplined motivated acts such as working hard, taking initiative, and following rules to support organizational objectives' (Van
Scotter \& Motowidlo, 1996, p. 525). Both types of performance have been posited to contribute to organizational effectiveness. While task performance contributes directly through the production of goods and services, contextual performance improves the context in which the technical core is embedded (Borman \& Motowidlo, 1993; Borman, White, \& Dorsey, 1995; Katz, 1964).

In view of the conceptualization of the employment relationship as one of exchange, organizational scholars have explained employee performance in terms of the fairness of an employee's exchanges with his/her organization. Because they are both underpinned by the theme of fairness, perceptions of politics and procedural justice have been shown to influence performance (Cohen-Charash \& Spector, 2001; Ferris et al., 2002; Witt, Kacmar, Carlson, \& Zivnuska, 2002).

From a social marketplace perspective (Cropanzano et al., 1997), political environments make for risky environments as there is no way of assuring the safety of one's investment in terms of time and effort. Accordingly, employees may be disinclined to invest in such an organizational environment. Perceptions of organizational politics have been shown to be related to neglect (Vigoda, 2001), and both interpersonal facilitation and job dedication facets of contextual performance (Witt et al., 2002). We, therefore, expect perceptions of organizational politics to be negatively related to task and contextual performance. In addition to the social marketplace explanation, Witt et al. (2002) explicated the negative influence of perceptions of organizational politics on contextual performance in terms of individuals immersing themselves in their work and, therefore, not interacting with coworkers beyond what is minimally required.

Based on the extant literature (Cohen-Charash \& Spector, 2001), we expect procedural justice to be positively related to task and contextual performance. Fairness in employee-organization exchanges will lead employees to perceive the work environment as less risky and will consequently, develop confidence in the safety of their investment of time and effort. Additionally and from a group value perspective (Lind \& Earley, 1991), procedural justice communicates to employees that they are valued by the organization. This creates an environment in which task and contextual performance occur.

Hypothesis 4a. Organizational politics will be negatively related to task performance, interpersonal facilitation, and job dedication.

Hypothesis 4b. Procedural justice will be positively related to task performance, interpersonal facilitation, and job dedication. 


\section{Method}

\section{Overview of the studies}

Based on data obtained from a manufacturing firm and a newspaper firm in India, the studies reported in this paper assessed the distinctiveness of organizational politics and procedural justice by examining their relationship and antecedents. In Study 1, we used data from both samples to examine the discriminant validity of organizational politics and procedural justice. Specifically, data from the manufacturing sample were used as the development sample and the confirmatory factor analysis (CFA) results provided a basis for modifying the measurement model. Then data from the newspaper sample were used to cross-validate the modified model. In Study 2, we used data from the manufacturing sample to examine the antecedents of organizational politics and procedural justice. Study 3 examined the consequences of organizational politics and procedural justice using data from the newspaper sample. The consequences were defined in terms of task performance and the interpersonal facilitation and job dedication facets of contextual performance.

\section{Study 1}

In this study, we examined the distinctiveness of the constructs of organizational politics and procedural justice with two samples, the manufacturing company sample and newspaper company sample.

\section{Sample 1 and procedure (manufacturing firm)}

Respondents in this sample were employees of a large marble manufacturing company in India. Work groups constitute the basic unit of work organization in the participating organization. Each work group was headed by a supervisor and it ranges in size from 5 to 15 employees. Work groups operating within the same department tend to be sequentially interdependent. The survey coordinator was requested to randomly select four employees from each work group and to ensure that the work groups were representative of the participating organization's workflow. Questionnaires were distributed to 280 employees representing 70 work groups. Attached to each questionnaire was a cover letter that explained the objective of the study, assured respondents of the confidentiality of their responses, and informed them of the voluntary nature of participation in the study. Because of the emotive nature of issues relating to the organizational marketplace, respondents were told that the study aimed to examine the influence of organizational design factors on their work-related experiences. Completed questionnaires were returned in sealed envelopes to a designated box in the human resources department.
Of the 280 questionnaires distributed, 223 completed questionnaires were returned representing a $79.6 \%$ response rate. We deleted 12 cases from four work groups in which respondents' ratings on the three unit level variables were below the recommended interrater agreement coefficient (IRC) of .70 (see Aggregation of individual level data described in Study 2). The data for this study were based on responses from 211 employees representing 66 work groups. Seventy-one percent of respondents were men. In terms of the age composition of the sample, $52.6 \%$ were in the below 30 years of age bracket, $37.5 \%$ in the $30-40$ age bracket, $7.7 \%$ in the $41-$ 50 age bracket, and $1.4 \%$ in the over 50 age bracket. Respondents reported a mean organizational tenure of 3.4 years, $40 \%$ had obtained university education and represented a mix of production, technical, and administrative employees.

\section{Sample 2 and procedure (newspaper firm)}

Respondents in this sample were employees of a regional newspaper located in northern India. Separate surveys were sent to respondents and their immediate supervisors. Supervisor surveys contained task and contextual performance while subordinate surveys contained measures of perceptions of organizational politics, procedural justice, and other variables not relevant to the purposes of this study. The supervisor surveys contained the code for both the supervisor and the subordinate, whereas the subordinate surveys contained only the subordinate code. A cover letter that explained the objective of the survey, assured respondents of the voluntary nature of participation in the survey, and confidentiality of their responses was attached to each survey.

Surveys were distributed to 260 subordinates and 65 supervisors representing a subordinate-supervisor ratio of 4:1. In other words, one supervisor evaluated four subordinates' task and contextual performance. Completed surveys were obtained from 213 subordinates and 58 supervisors, respectively. Deletion of respondents with excessive missing data and/or could not be matched to supervisors resulted in a sample size of 203 subordinates and 55 supervisors. The majority of the subordinate respondents $(83.0 \%)$ were men. In terms of age composition of the sample, $53.5 \%$ were in the under 30 age bracket, $37.2 \%$ in the $30-40$ age bracket, $8.1 \%$ in the $41-50$ age bracket, and $1.2 \%$ in the over 50 age bracket. Respondents reported a mean organizational tenure of 3.5 years, over $74.7 \%$ had obtained university education, and were in administrative and professional positions. The supervisors reported an average age of 38 years $(S D=9.50)$ and were predominantly men $(90.8 \%)$. They reported a mean organizational tenure of 3.79 years with over $63.5 \%$ having obtained university education. In terms of position in the managerial hierarchy, 39.9\% were in middle, $52.6 \%$ in senior, and $7.5 \%$ in top level management positions. 


\section{Measures}

Unless otherwise indicated, response options ranged from (1) 'strongly disagree' to (5) 'strongly agree.'

Procedural justice. A 7-item scale developed by Moorman (1991) was used to measure procedural justice. Sample items are "My present organization has procedures designed to generate standards so that decisions could be made with consistency" and "My present organization has procedures designed to provide useful feedback regarding a decision and its implementation." The scale's $\alpha$ reliability in Sample 1 is .83 and .90 in Sample 2.

Organizational politics. An 8-item shortened version of a scale developed by Kacmar and Ferris (1991) was used to measure organizational politics. Sample items are "Favoritism rather than merit determines who gets ahead in this organization," and "The stated pay and promotion policies have nothing to do with how pay raises and promotions are determined." The scale's $\alpha$ reliability in Sample 1 is .75 and .80 in Sample 2.

\section{Assessing discriminant validity}

To assess the discriminant validity of the two constructs, we performed three separate CFAs with data from Sample 1 as the development sample and data from Sample 2 as the validation sample. Results of the CFA based on Sample 1 showed that the $\chi^{2}$ value for the 2-factor model $\left(\chi^{2}=229.98, d f=89, p<.01\right)$ was significantly lower $\left(\Delta \chi^{2}=292.16, \Delta d f=1, p<.01\right)$ than that for the 1 -factor model $\left(\chi^{2}=522.14, d f=90\right.$, $p<.01)$. Additionally, all the fit indices showed a better fit for the 2-factor model $(\mathrm{TLI}=.89, \quad \mathrm{CFI}=.90$, RMSEA $=.09$ ) than the 1 -factor model (TLI $=.65$; $\mathrm{CFI}=.70$, RMSEA = .19). However, the fit indices for the 2-factor model indicates a good fit. A close inspection of the CFA results revealed the standardized loading for one of the items of organizational politics was unacceptably low (.27) and was deleted. After deleting that item, we conducted another CFA based on data from Sample 1. The CFA results provided support for a 2-factor model of the organizational politics and procedural justice constructs. The $\chi^{2}$ value for the 2factor model $\left(\chi^{2}=182.42, \mathrm{df}=76, p<.01\right)$ was significantly lower $\left(\Delta \chi^{2}=127.43, \Delta d f=1, p<.01\right)$ than that for the 1 -factor model $\left(\chi^{2}=309.85, d f=77, p<.01\right)$. Further, the fit indices showed a better fit for the 2factor model $(\mathrm{TLI}=.91, \mathrm{CFI}=.93, \mathrm{RMSEA}=.07)$ relative to the 1 -factor model $(\mathrm{TLI}=.81, \mathrm{CFI}=.84$, RMSEA = .13).

The CFA results based on data from Sample 2 that served as the validation sample provided support for a 2-factor model indicating the distinctiveness of the organizational politics and procedural justice constructs. The $\chi^{2}$ value for the 2 -factor model $\left(\chi^{2}=137.34\right.$, $d f=76, p<.01)$ was significantly lower $\left(\Delta \chi^{2}=242.16\right.$, $\Delta d f=1, p<.01)$ than that for the 1 -factor model $\left(\chi^{2}=379.50, d f=77, p<.01\right)$. Further, the fit indices showed a better fit for the 2-factor model (TLI $=.96$, $\mathrm{CFI}=.97, \mathrm{RMSEA}=.06)$ relative to the 1 -factor model $(\mathrm{TLI}=.82, \mathrm{CFI}=.85$, RMSEA $=.17)$. Based on these CFA results, we used a 7-item scale to measure organizational politics in the two subsequent studies. The .75 $\alpha$ reliability of the organizational politics scale in Sample 1 and .80 in Sample 2 are comparable to previous research that also used a shortened organizational politics scale. For example, Parker et al. (1995) reported an $\alpha$ reliability of .76 and Vigoda (2001), an $\alpha$ reliability of 79 .

\section{Study 2}

In this study, we examined the antecedents of organizational politics and procedural justice with Sample 1.

\section{Measures}

In addition to the organizational politics and procedural justice measures reported in Study 1, we measured the following variables:

Formalization. A 6-item scale developed by Podsakoff and MacKenzie (1994) was used to measure formalization. Response options ranged from (1) 'not at all accurate' to (5) 'accurate to a large extent.' Sample items are "Clear written goals and objectives exist for my job" and "Written rules and guidelines exist to direct my work efforts." The scale's $\alpha$ reliability in this study is .87 .

Centralization. Two dimensions of centralization-hierarchy of authority and participation in decision making were measured using scales developed by Hage and Aiken (1967).

Hierarchy of authority. A 5-item scale with response options ranging from (1) 'definitely false' to (4) 'definitely true' was used to measure hierarchy of authority. Sample items are "A person who wants to make his/her own decisions would be quickly discouraged" and "There can be little action here until a supervisor approves a decision." The scale's $\alpha$ reliability is .70.

Participation in decision making. A 4-item scale with response options ranging from (1) 'never' to (5) 'always' was used to measure participation in decision making. Sample items are "How frequently do you actually participate in the decision to hire new staff?" and "How frequently do you participate in decisions on the adoption of new programs?" The scale's $\alpha$ reliability in this study is .79.

Spatial distance. A 4-item scale developed by Podsakoff, Niehoff, MacKenzie, and William (1993) was used to measure spatial distance. Sample items are "The nature of my job is such that my immediate supervisor is seldom around me when I'm working" and "On my job, my most important tasks take place away from where my immediate supervisor is located." The scale's $\alpha$ reliability in this study is .70 . 


\section{Aggregation of individual level data}

Data for all the measures were obtained at the individual level. However, formalization, authority, and participation reflect organizational level variables. In order to make the level of the data consistent with the level of the theory, we aggregated data for these three measures to the organizational or group level. A major condition for aggregation of data from individual to group level is interrater agreement (George \& James, 1993; James, Demaree, \& Wolf, 1984). We tested for interrater agreement using the interrater agreement coefficient (IRC) developed by James et al. (1984). They recommended an IRC of .70 as an indicator of interrater agreement. However, of the 70 work groups, four had an IRC below .70 so they were dropped from further analysis. Across the 66 work groups that constituted our sample, the IRC for formalization ranged from .73 to .93 , for hierarchy of authority ranged from .71 to .91, and for participation in decision making ranged from .74 to .95 .

\section{Data analysis}

First, we conducted a CFA to examine the distinctiveness of organizational politics and procedural justice, and their hypothesized structural antecedents of formalization, hierarchy of authority, participation in decision making, and spatial distance. Second, the hypotheses were tested with structural equation modeling (SEM) using LISREL 8 (Jöreskog \& Sörbom, 1996). Given the small sample relative to the measurement items, we employed procedures recommended in the extant literature (Bagozzi \& Heatherton, 1994; Brooke, Russell, \& Price, $1988)$ to reduce the number of items by creating two indicators for each construct. On the basis of factor analysis results, the items with the highest and lowest loadings for each construct were combined first, followed by items with the next highest and lowest loadings until all the items for each construct had been assigned to an indica- tor. In addition to the paths shown in Fig. 1, the model freely estimated the covariances among the latent exogenous variables and the residuals of the latent endogenous variables. To assess model fit, we used the overall $\chi^{2}$ model measure, the Tucker-Lewis Index (TLI, Tucker \& Lewis, 1973), the comparative fit index (CFI, Bentler, 1990) and the root mean square error of approximation (RMSEA, Browne \& Cudeck, 1993).

\section{Results}

Confirmatory factor analysis. The CFA results provided support for the hypothesized 6-factor model indicating the distinctiveness of the six constructs. The $\chi^{2}$ value for the 6-factor model $\left(\chi^{2}=77.00, d f=39, p<.01\right)$ was significantly lower $\left(\Delta \chi^{2}=77.90, \Delta d f=5, p<.01\right)$ than that for the 5-factor model 1 (combining the two dimensions of centralization, hierarchy of authority, and participation in decision making; $\chi^{2}=154.90, d f=44$, $p<.01)$, significantly lower $\left(\Delta \chi^{2}=69.44, \Delta d f=5\right.$, $p<.01$ ) than the 5-factor model 2 (combining organizational politics and procedural justice; $\chi^{2}=146.44$, $d f=44, p<.01)$, and significantly lower $\left(\Delta \chi^{2}=305.17\right.$, $\Delta d f=15, \quad p<.01)$ than the 1 -factor model $\left(\chi^{2}=382.17, d f=54, p<.01\right)$. Further, the fit indices showed a better fit for the 6-factor model (TLI $=.90$, $\mathrm{CFI}=.94, \mathrm{RMSEA}=.06$ ) relative to the 5 -factor model $1(\mathrm{TLI}=.77, \mathrm{CFI}=.84, \mathrm{RMSEA}=.10)$, the 5 -factor model $2(\mathrm{TLI}=.75, \mathrm{CFI}=.83$, RMSEA $=.11)$, and the 1 -factor model $(\mathrm{TLI}=.39, \mathrm{CFI}=.50, \mathrm{RMSEA}=.17)$.

Table 1 presents the descriptive statistics and zeroorder correlations among the study variables. As shown, organizational politics was negatively related to procedural justice $(r=-.38, p<.01)$. Further, formalization, hierarchy of authority, participation in decision making, and spatial distance were all related to organizational politics while only formalization and participation in decision making were related to procedural justice.

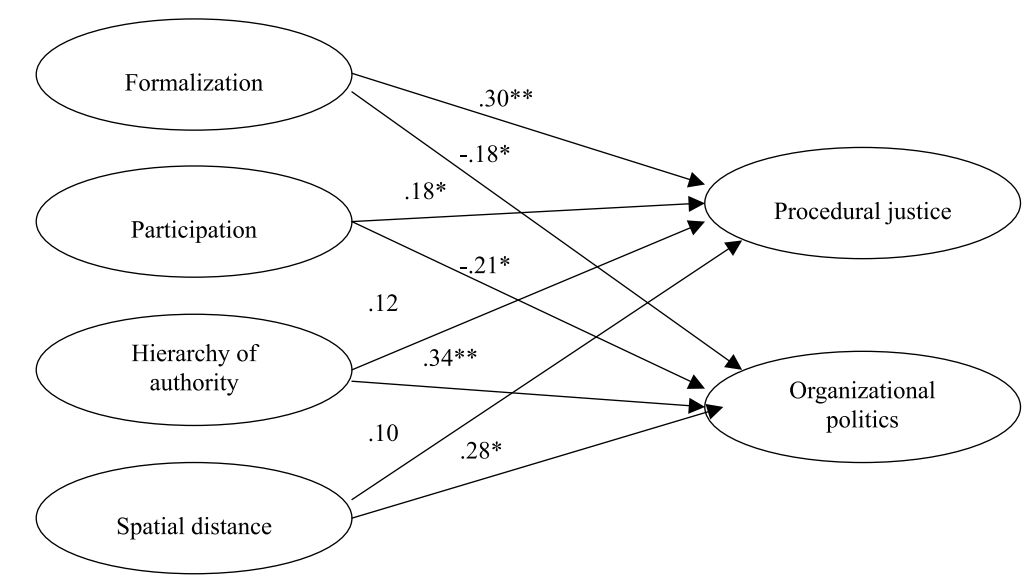

Fig. 1. Structural equation modeling results for Study 2. Note. $\chi^{2}=77.00, d f=39(p<.01)$; TLI $=.90$, CFI $=.94$, and RMSEA $=.06$. 
Table 1

Means, standard deviations, and zero-order correlations for Study 2

\begin{tabular}{|c|c|c|c|c|c|c|c|c|}
\hline Variables & Mean & $S D$ & 1 & 2 & 3 & 4 & 5 & 6 \\
\hline 1. Formalization & 3.22 & .69 & {$[.87]$} & & & & & \\
\hline 2. Hierarchy of authority & 2.51 & .45 & -.13 & {$[.70]$} & & & & \\
\hline 3. Participation in decision making & 2.52 & .78 & $.39^{* *}$ & -.07 & {$[.79]$} & & & \\
\hline 4. Spatial distance & 2.78 & .52 & .06 & -.12 & .03 & {$[.70]$} & & \\
\hline 5. Procedural justice & 3.57 & .52 & $.40^{* *}$ & -.08 & $.27^{* *}$ & .10 & {$[.83]$} & \\
\hline 6. Organizational politics & 2.70 & .58 & $-.29^{* *}$ & $.35^{* *}$ & $-.26^{* *}$ & $.22^{* *}$ & $-.38^{* *}$ & {$[.75]$} \\
\hline
\end{tabular}

Note. $N=211$. Figures in parentheses are $\alpha$ reliabilities.

${ }^{* *} p<.01$.

Tests of hypotheses. Fig. 1 presents the standardized LISREL estimates for the hypothesized antecedents of organizational politics and procedural justice. As shown in that figure, formalization $(\beta=-.18, p<.05)$, participation in decision making $(\beta=-.21, p<.05)$, hierarchy of authority $(\beta=.34, p<.01)$, and spatial distance $(\beta=.28, p<.01)$ were all related to organizational politics. However, only formalization $(\beta=.30$, $p<.01)$ and participation in decision making $(\beta=.18$, $p<.05)$ were related to procedural justice. Thus, with the exception of the hypothesized influence of hierarchy of authority (Hypothesis 2b) and spatial distance (Hypothesis 3 ) on procedural justice, all the hypothesized relationships received support. The fit indices revealed an acceptable fit of the model to the data $\left(\chi^{2}=77.00\right.$, $d f=39, p<.01 ; \mathrm{TLI}=.90 ; \mathrm{CFI}=.94 ; \mathrm{RMSEA}=.06$ )

\section{Study 3}

In this study, we examined the consequences of organizational politics and procedural justice with Sample 2.

\section{Measures}

In addition to the organizational politics and procedural justice measures reported in Study 1, we measured the following variables:

Task performance. Supervisors rated the task performance of their subordinates with a 6-item abbreviated version of a scale by Tsui, Pearce, Porter, and Tripoli (1997). Sample items are "This employee's quality of work is much higher than average" and "This employee's standards of work quality are higher than the formal standards for his/her job." The scale's $\alpha$ reliability in this study is .84 .

Contextual performance. Supervisors rated the contextual performance of their subordinates using a 15-item scale by Motowidlo and Van Scotter (1994). Response options ranged from (1) 'not at all likely' to (5) 'extremely likely.' Following the stem 'While performing his/her job, how likely is it that this employee would," the supervisor indicated the likelihood of a subordinate to "...... talk to others before taking actions that might affect them?" (interpersonal facilitation), and "..... ask for a challenging work assignment?" and "...... take the initiative to solve a work problem?" (job dedication).

To test the assumption of independence among the performance ratings that each supervisor provided for multiple (2-4) subordinates, we followed Dansereau, Alutto, and Yammarino (1984), and conducted a within and between analysis (WABA). The E-ratios (tests of practical significance) for each measure were all less than 1.0 (ranging from .78 to .83) suggesting that variation within groups was significantly greater than variation between groups. Second, adjusted $F$ test (tests of statistical significance) was computed for each measure, and none was statistically significant. Together, the WABA results supported the assumption of independence for all three measures and the appropriateness of conducting the analysis at the individual rather than the group level.

\section{Data analysis}

Following Anderson and Gerbing's (1988) recommendation, a two-step procedure involving CFA and SEM was employed to test our hypotheses. In the first step, we conducted a CFA to examine the distinctiveness of organizational politics, procedural justice and the performance measures of task performance, interpersonal facilitation, and job dedication. In the second step, we tested the hypothesized influence of organizational politics and procedural justice on the performance measures with SEM using LISREL 8 (Jöreskog \& Sörbom, 1996). Given the small sample relative to the measurement items, we employed procedures recommended in the extant literature (Bagozzi \& Heatherton, 1994; Brooke et al., 1988) to reduce the number of items by creating two indicators for each construct. On the basis of factor analysis results, the items with the highest and lowest loadings for each construct were combined first, followed by items with the next highest and lowest loadings until all the items for each construct had been assigned to an indicator. In addition to the paths shown in Fig. 2, the model freely estimated the covariances among the latent exogenous variables and the residuals of the latent endogenous variables. To assess model fit, we used the overall $\chi^{2}$ model measure, the Tucker-Lewis Index (TLI, Tucker \& Lewis, 1973), the comparative fit 


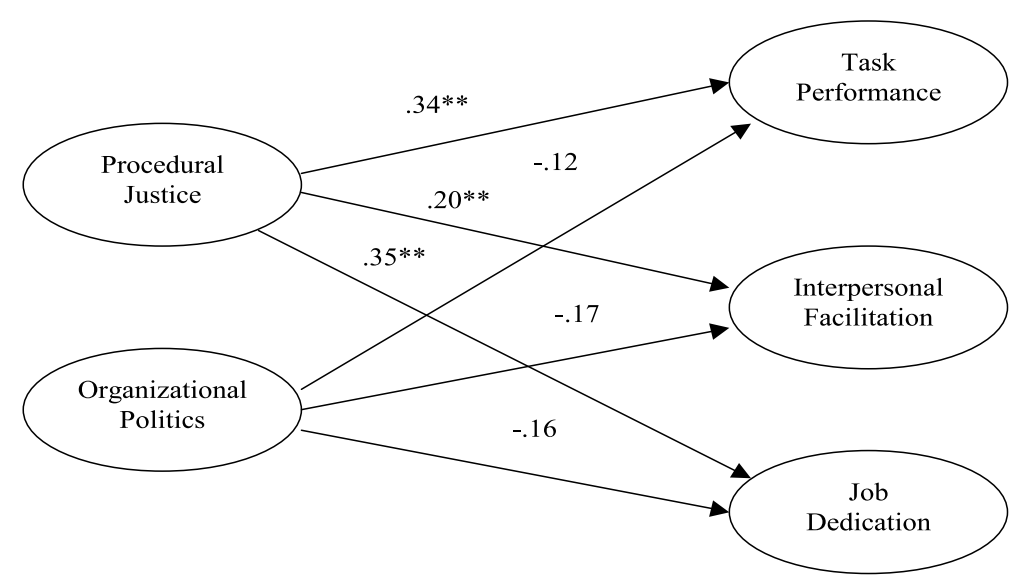

Fig. 2. Structural equation modeling results for Study 3. Note, $\chi^{2}=63.26, d f=25(p<.01)$; TLI $=.94$, CFI $=.97$, and RMSEA $=.08$.

index (CFI, Bentler, 1990) and the root mean square error of approximation (RMSEA, Browne \& Cudeck, 1993).

\section{Results}

Confirmatory factor analysis. The results of the CFA provided support for a 5-factor model indicating the distinctiveness of the constructs studied. The $\chi^{2}$ value for the 5-factor model $\left(\chi^{2}=63.26, d f=25, p<.01\right)$ was significantly lower $\left(\Delta \chi^{2}=49.39, \Delta d f=4, p<.01\right)$ than that for the 4-factor model 1 (combining organizational politics and procedural justice; $\chi^{2}=112.65, d f=29$, $p<.01)$, significantly lower $\left(\Delta \chi^{2}=17.59, \Delta d f=4\right.$, $p<.01$ ) than the 4-factor model 2 (combining interpersonal facilitation and job dedication; $\chi^{2}=80.85$, $d f=29, p<.01)$, and significantly lower $\left(\Delta \chi^{2}=257.49\right.$, $\Delta d f=10, \quad p<.01) \quad$ than the 1 -factor model $\left(\chi^{2}=320.75, d f=35, p<.01\right)$. Further, the fit indices showed a better fit for the 5-factor model (TLI $=.94$, $\mathrm{CFI}=.97, \mathrm{RMSEA}=.08$ ) relative to the 4 -factor model $1(\mathrm{TLI}=.89, \mathrm{CFI}=.93$, RMSEA $=.11)$, the 4 -factor model $2(\mathrm{TLI}=.93, \mathrm{CFI}=.96, \mathrm{RMSEA}=.10)$, and the 1 -factor model $(\mathrm{TLI}=.69, \mathrm{CFI}=.76, \mathrm{RMSEA}=.20)$.

Table 2 presents the descriptive statistics and zero-order correlations of the variables studied. As shown in that table, organizational politics and procedural justice were related to the work outcomes in the expected direction.
Test of hypotheses. Fig. 2 presents the SEM results that examined the hypothesized influence of organizational politics and procedural justice on the outcomes of task performance, and the interpersonal facilitation and job dedication dimensions of contextual performance. As shown in that figure, procedural justice was related to task performance $(\beta=.34, p<.01)$, interpersonal facilitation $(\beta=.20, p<.01)$, and job dedication $(\beta=.35$, $p<.01)$ providing support for Hypothesis $4 \mathrm{~b}$. However, Hypothesis 4 a did not receive support as organizational politics was unrelated to any of the performance measures. The $\chi^{2}$ value of $63.26(d f=25)$ and the fit indices $(\mathrm{TLI}=.94 ; \mathrm{CFI}=.97$; RMSEA $=.08)$ indicate an adequate fit of the model to the data. The differential influence of organizational politics and procedural justice on the performance measures provide yet another evidence of the distinctiveness of the two constructs.

\section{Discussion}

The conceptualization of the employment relationship as one of exchange makes the fairness of employee rewards a critical motivational underpinning of work attitudes and behaviors. Two intertwined constructs that are germane to the fairness of rewards employees obtain from the organizational marketplace are organizational politics and procedural justice. Based on data

Table 2

Means, standard deviations, and zero-order correlations for Study 3

\begin{tabular}{lllccccc}
\hline Variables & Mean & $S D$ & 1 & 2 & 3 & 4 \\
\hline 1. Organizational politics & 2.75 & .62 & {$[.80]$} & & & & \\
2. Procedural justice & 3.47 & .65 & $-.33^{* *}$ & {$[.90]$} & & \\
3. Task performance & 3.57 & .56 & $-.15^{*}$ & $.33^{* *}$ & {$[.84]$} & $.51^{* *}$ & {$[.83]$} \\
4. Interpersonal facilitation & 3.52 & .53 & $-.20^{* *}$ & $.30^{* *}$ & $.66^{* *}$ & $.67^{* *}$ & {$[.87]$} \\
5. Job dedication & 3.60 & .59 & $-.17^{*}$ & $.32^{* *}$ & $.66^{*}$ & \\
\hline
\end{tabular}

Note. $N=176$. Figures in parentheses are $\alpha$ reliabilities.

${ }_{* *}^{*}<.05$.

${ }^{*} p<.01$. 
obtained from two organizations (manufacturing and newspaper) in India, this paper reports the findings of three separate studies that examined the relationship between these two constructs. Study 1 assessed the relationship between organizational politics and procedural justice using data from both samples. Study 2 examined the antecedents of organizational politics and procedural justice with data from the manufacturing sample. Study 3 examined the consequences of organizational politics and procedural in terms of task and contextual performance with data from the newspaper sample.

The CFA results from Study 1 provided evidence of the discriminant validity of organizational politics and procedural justice. Modifications of the measures of organizational politics and procedural justice based on data from the manufacturing sample were validated with data from the newspaper sample. Given that our findings were based on a separate development and validation sample, these findings should reinforce confidence in previous research that reported organizational politics and procedural justice to be distinct constructs (Andrews \& Kacmar, 2001). Pertaining to the structural antecedents, formalization and participation in decision making were positively related to procedural justice but negatively related to organizational politics. Formalization facilitates due-process and rule-constrained practices which lead to increased perceptions of procedural justice (Andrews \& Kacmar, 2001). This is because formalization encourages consistent treatment of employees considered a defining attribute of the level of bureaucratization (Pearce et al., 1998). Because of the consistent treatment of employees that formalization fosters, it eliminates uncertainty and ambiguity leading to decreased perceptions of organizational politics. Similar to Schminke and his colleagues' $(2000,2002)$ findings, participation in decision making or decentralizing power related to task was related to procedural justice. However, contrary to their findings, ours revealed hierarchy of authority or decentralizing decision making related to departmental policies or procedures to be unrelated to procedural justice. This pattern of findings underlines the crucially important role of control over day-to-day tasks that task-related participation engenders in perceptions of procedural justice.

As predicted, our findings revealed the two dimensions of centralization to be related to organizational politics but in opposite directions. Participation in taskrelated decisions was negatively related to perceptions of organizational politics. Prior research has reported the conceptually similar construct of task autonomy to be negatively related to organizational politics (Ferris \& Kacmar, 1992). This relationship is explicable in terms of the empowering potential of participation in taskrelated decisions leading to reduced perceptions of organizational politics. The positive influence of hierarchy of authority is consistent with the reported influence of centralization on organizational politics (Andrews \& Kacmar, 2001; Valle \& Perrewé, 2000). Unlike task-related decisions, decisions involving departmental policies and procedures may be characterized by uncertainty and disagreements due to the absence of clear, objective criteria thereby precipitating increased perceptions of organizational politics (Gandz \& Murray, 1980).

Consistent with our prediction, spatial distance was related to organizational politics in the predicted direction but unrelated to procedural justice. Being involved in a spatially distant relationship with the supervisor may cause an employee to lack understanding of decisions made by the supervisor leading to increased perceptions of organizational politics. Given that much research has shown span of control, a conceptually similar construct to be unrelated to organizational politics (Kacmar \& Baron, 1999; Valle \& Perrewé, 2000), future research should examine spatial distance rather than span of control as an antecedent of organizational politics.

Study 2 was partially motivated by a concern to examine multi-level issues in research on the antecedents of organizational politics, the neglect of which may threaten statistical conclusion validity. Our findings indicate that the influence of formalization on politics perceptions was consistent with findings of research that reduced structural antecedents to individual level phenomena (Andrews \& Kacmar, 2001; Valle \& Perrewé, 2000). This, however, does not diminish the purported threat to statistical conclusion validity. Future research should, therefore, respond to Ferris et al.'s (2002) call and examine multiple level antecedent conditions on the individual's perceptions of politics. Additionally, future research should examine the two dimensions of centralization since they were found to be related to politics perceptions in opposite directions.

The SEM analysis that examined the consequences of organizational politics and procedural justice provided mixed support for our propositions. While procedural justice was related to all the performance measures contrary to previous findings, organizational politics was unrelated to task performance (Ferris et al., 2002) and the interpersonal facilitation and job dedication facets of contextual performance (Witt et al., 2002). It is worth noting that previous research that reported organizational politics to be related to the performance measures examined here did not control for procedural justice (Cropanzano et al., 1997). Our findings suggest that procedural justice might mediate the relationship between organizational politics and these performance dimensions. Indeed, organizational politics has been posited to decrease perceptions of procedural justice (Ambrose \& Harland, 1995; Dulebohn, 1997). Given the cross-sectional data, we were unable to examine the causal status of the relationship between organizational 
politics and procedural justice. Future research with longitudinal data should examine the possibility of procedural justice mediating the influence of organizational politics on the performance measures examined here. A steady stream of research has reported procedural justice to be related to both in-role and citizenship behaviors (Cohen-Charash \& Spector, 2001; Colquitt, Conlon, Wesson, Porter, \& Ng, 2001). The influence of procedural justice on work performance is explicable in terms of group value theory and social exchange. Operating within a social exchange perspective, Organ (1990) argued that procedural justice suggests that an organization can be trusted to protect the interests of its employees. This engenders an obligation on the part of employees to reciprocate fair employee-organization exchanges with behaviors that promote organizational effectiveness.

The findings reported here have both theoretical and practical implications. Theoretically, this study has provided evidence for the generalizability of the distinctiveness of organizational politics and procedural justice, two key constructs that underpin employee-organization exchanges to a nonWestern context. Further, although these constructs have generated separate research streams, our findings indicate that they could be combined to provide better insights into the motivational underpinnings of employee work performance. A direction for future research suggested by our findings is the need to examine, preferably using a cross-national sample with longitudinal data, an integrated model of the influence of organizational structure on employee perceptions of fairness of exchanges with the organization which in turn, influence their work-related behaviors (Ambrose \& Schminke, 2003; Ferris et al., 2002). A practical implication of the antecedents of organizational politics and procedural justice examined here relates to the design of the social context of work in order to facilitate fair exchange of resources at the organizational marketplace. Essentially, the social context of work could be designed in accordance with the purposive, meritocratic, and universalistic objectives of Weber's (1947) ideal type bureaucracy. Instead of the dysfunctional consequences of bureaucratic rigidity particularly in the increasingly unpredictable environment of today's organizations, emphasis should be placed on organizational practices that promote universalistic principles (Pearce et al., 2000) which in turn, engender fairness in employee-organization exchanges. Indeed, Schminke et al. (2002) also alluded to how the constitution or design of large bureaucratic organizations can impact on employee work lives through the fairness of their exchanges with these organizations.

The findings and their implications are tempered by the limitations of this study. First, the cross-sectional methodology constrains the extent to which cause-effect relations can be inferred from our findings. Second, both organizational politics and procedural justice were based on self-reports. However, the modest correlations between these variables and the results of the factor analyses suggest that our findings are substantive and not entirely attributable to method variance. Third, although our findings resonate with those reported in the extant Western literature, we are unsure whether politics perceptions and procedural justice have the same connotations in India as they do, for example, in the United States. Relatedly, although the abbreviated scales used to measure politics perceptions and task performance showed acceptable $\alpha$ reliabilities, their validity is unknown. Future research should consider using Kacmar and Carlson's (1997) more recent and refined scale of organizational politics perceptions. Lastly, given the generally young sample, we urge caution when comparing our results to those in the extant literature as we were unable to ascertain the extent to which our findings are applicable to an older sample.

\section{Conclusion}

The results of the factor analyses and the differential influence of the antecedents on organizational politics and procedural justice indicate the generalizability of the demonstrated distinctiveness of these constructs to India, a developing country. Further, results of the SEM analysis that examined the consequences of organizational politics and procedural justice coupled with findings in the extant literature provide preliminary evidence of a possible mediating influence of procedural justice on the relationship between organizational politics and the performance measures of task performance, interpersonal facilitation, and job dedication. Given the importance of fairness as a motivational underpinning of employee work performance, an important task for management is to design organizational structures that engender fairness in employee-organization exchanges.

\section{References}

Ambrose, M. L., \& Harland, L. K. (1995). Procedural justice and influence tactics: Fairness, frequency, and effectiveness. In R. S. Cropanzano \& K. M. Kacmar (Eds.), Organizational politics, justice, and support (pp. 97-130). Westport, CT: Quorum Books.

Ambrose, M. L., \& Schminke, M. (2003). Organizational structure as a moderator of the relationship between procedural justice, perceived organizational support, and supervisory trust. Journal of Applied Psychology, 88, 295-306.

Anderson, J. C., \& Gerbing, D. W. (1988). Structural equation modeling in practice: A review and recommended two-step approach. Psychological Bulletin, 103, 411-423.

Andrews, M. C., \& Kacmar, K. M. (2001). Discriminating among organizational politics, justice, and support. Journal of Organizational Behavior, 22, 347-366. 
Bagozzi, R., \& Heatherton, T. (1994). A general approach to representing multifaceted personality constructs: Application to self-esteem. Structural Equation Modeling, 1, 35-67.

Bentler, P. M. (1990). Comparative fit indexes in structural models. Psychological Bulletin, 107, 238-246.

Borman, W. C., \& Motowidlo, S. J. (1993). Expanding the criterion domain to include elements of contextual performance. In $\mathrm{N}$. Schmitt, W. C. Borman, \& Associates (Eds.), Personnel selection in organizations (pp. 71-98). San Francisco, CA: Jossey-Bass.

Borman, W. C., White, L. A., \& Dorsey, D. W. (1995). Effects of rate task performance and interpersonal factors on supervisor and peer performance ratings. Journal of Applied Psychology, 80, 168-177.

Brooke, P. P., Russell, D. W., \& Price, J. L. (1988). Discriminant validation of measures of job satisfaction, job involvement, and organizational commitment. Journal of Applied Psychology, 73, 139-145.

Browne, M. W., \& Cudeck, R. (1993). Alternative ways of assessing model fit. In K. A. Bollen \& J. S. Long (Eds.), Testing structural equation models (pp. 136-162). Newbury Park, CA: Sage.

Campbell, J. P. (1990). Modeling the performance prediction problem in industrial and organizational psychology. In M. D. Dunnete, L. M. Hough (Eds.), Handbook of industrial and organizational psychology (2nd ed., Vol. 1, pp. 687-732). Palo Alto, CA: Consulting Psychologists Press.

Cohen-Charash, Y., \& Spector, P. E. (2001). The role of justice in organizations: A meta-analysis. Organizational Behavior and $\mathrm{Hu}$ man Decision Processes, 86, 278-321.

Colquitt, J. A., Conlon, D. E., Wesson, M. J., Porter, C., \& Ng, K. Y. (2001). Justice at the millennium: A meta-analytic review of 25 years of organizational justice research. Journal of Applied Psychology, 86, 425-445.

Conway, J. M. (1999). Distinguishing contextual performance from task performance for managerial jobs. Journal of Applied Psychology, 84, 3-13.

Cropanzano, R., Howes, J. C., Grandey, A. A., \& Toth, P. (1997). The relationship of organizational politics and support to work behaviors, attitudes, and stress. Journal of Organizational Behavior, 18, 159-180.

Cropanzano, R., Prehar, C., \& Chen, P. Y. (2002). Using social exchange theory to distinguish procedural from interactional justice. Group and Organizational Management, 27, 324-351.

Dansereau, F., Alutto, J. A., \& Yammarino, F. J. (1984). Theory testing in organization behavior: The variant approach. Englewood Cliffs, NJ: Prentice-Hall.

Drory, A., \& Romm, T. (1988). What organizational politics is: Organization members' perceptions. Organization Studies, 9, 165179.

Dulebohn, J. H. (1997). Social influence in justice evaluations of human resources systems. In G. R. Ferris (Ed.), Research in personnel and human resources management (Vol. 15, pp. 241-291). Greenwich, CT: JAI Press.

Ferris, G. R., Adams, G., Kolodinsky, R. W., Hochwarter, W. A., \& Ammeter, A. P. (2002). Perceptions of organizational politics: Theory and research directions. In F. J. Yammarino \& F. Dansereau (Eds.), Research in multi-level issues volume 1: The many faces of multi-level issues (pp. 179-254). Boston: JAI Press.

Ferris, G. R., Brand, J. F., Brand, S., Rowland, K. M., Gilmore, D. C., King, T. R., Kacmar, K. M., \& Burton, C. A. (1993). Politics and control in organizations. In E. J. Lawler, B. Markovsky, J. O'Brien, \& K. Heine (Eds.), Advances in group processes (Vol. 10, pp. 83-111). Greenwich, CT: JAI Press.

Ferris, G. R., Frink, D. D., Bhawuk, D. P. S., Zhou, J., \& Gilmore, D. C. (1996). Reactions of diverse groups to politics in the workplace. Journal of Management, 22, 23-44.

Ferris, G. R., Frink, D. D., Galang, M. C., Zhou, J., Kacmar, K. M., \& Howard, J. E. (1996). Perceptions of organizational politics:
Predictions, stress-related implications, and outcomes. Human Relations, 49, 233-266.

Ferris, G. R., Harrell-Cook, G., \& Dulebohn, J. H. (2000). Organizational politics: The nature of the relationship between politics perceptions and political behavior. In S. B. Bacharach \& E. J. Lawler (Eds.), Research in the sociology of organizations (Vol. 17, pp. 89-130). Stamford, CT: JAI Press.

Ferris, G. R., Judge, T. A., Rowland, K. M., \& Fitzgibbons, D. E. (1994). Subordinate influence and the performance evaluation process: Test of a model. Organizational Behavior and Human Decision Processes.

Ferris, G. R., \& Kacmar, K. M. (1992). Perceptions of organizational politics. Journal of Management, 18, 93-116.

Ferris, G. R., Russ, G. S., \& Fandt, P. M. (1989). Politics in organizations. In R. A. Giacalone \& P. Rosenfeld (Eds.), Impression management in organizations (pp. 143-170). Newbury Park, CA: Sage.

Folger, R., \& Greenberg, J. (1985). Procedural justice: An interpretive analysis of personnel systems. In K. Rowland \& G. R. Ferris (Eds.), Research in personnel and human resources management (Vol. 3, pp. 141-183). Greenwich, CT: JAI Press.

Gandz, J., \& Murray, V. V. (1980). The experience of workplace politics. Academy of Management Journal, 23, 237-251.

George, J. M., \& James, L. R. (1993). Personality, affect, and behavior in groups revisited: Comment on aggregation, levels of analysis and a recent application of within and between analysis. Journal of Applied Psychology, 78, 798-804.

Hage, J., \& Aiken, M. (1967). Relationship of centralization to other structural properties. Administrative Science Quarterly, 12, 72-92.

Harrell-Cook, G., Ferris, G. R., \& Dulebohn, J. H. (1999). Political behaviors as moderators of the perceptions of organizational politics-work outcome relationships. Journal of Organizational Behavior, 20, 1093-1106.

James, L. R., Demaree, R. G., \& Wolf, G. (1984). Estimating withingroup interrater reliability with and without response bias. Journal of Applied Psychology, 69, 85-98.

Jöreskog, K. G., \& Sörbom, D. (1996). LISREL 8: User's reference guide. Chicago: Scientific Software International.

Kacmar, K. M., \& Carlson, D. S. (1997). Further validation of the perceptions of politics scale (POPS): A multiple sample investigation. Journal of Management, 23, 627-658.

Kacmar, K. M., \& Baron, R. A. (1999). Organizational politics: The state of the field, links to related processes, and an agenda for future research. In G. R. Ferris (Ed.), Research in personnel and human resources management (Vol. 17, pp. 1-39). Stamford, CT: JAI Press.

Kacmar, K. M., Bozeman, D. P., Carlson, D. S., \& Anthony, W. P. (1999). An examination of the perceptions of organizational politics model: Replication and extension. Human Relations, 52, 383-416.

Kacmar, K. M., \& Ferris, G. R. (1991). Perceptions of organizational politics scale (POPS): Development and construct validation. Educational and Psychological Measurement, 51, 193-205.

Katz, D. (1964). The motivational basis of organizational behavior. Behavioral Science, 9, 131-146.

Kerr, S., \& Jermier, J. M. (1978). Substitutes for leadership: Their meaning and measurement. Organizational Behavior and Human Performance, 22, 375-403.

Leventhal, G. S. (1980). What should be done with equity theory? In K. J. Gergen, M. S. Greenberg, \& R. H. Willis (Eds.), Social exchange: Advances in theory and research (pp. 27-55). New York: Plenum Press.

Leventhal, G. S., Karuza, J., \& Fry, W. R. (1980). Beyond fairness: A theory of allocation preferences. In G. Mikula (Ed.), Justice and social interaction (pp. 121-145). New York: Springer-Verlag.

Lewin, K. (1936). Principles of topological psychology. New York: McGraw-Hill. 
Lind, E. A., \& Earley, P. C. (1991). Some thoughts on self and group interests: A parallel-processor model. Paper presented at the annual meeting of the Academy of Management, Miami.

Madison, D. L., Allen, R. W., Porter, L. W., Renwick, P. A., \& Mayes, B. T. (1980). Organization politics: An exploration of managers' perceptions. Human Relations, 33, 79-100.

Masterson, S. S., Lewis, K., Goldman, B. M., \& Taylor, M. S. (2000). Integrating justice and social exchange: The differing effects of fair procedures and treatment on work relationships. Academy of Management Journal, 43, 738-748.

Mintzberg, H. (1985). The organization as political arena. Journal of Management Studies, 22, 133-154.

Moorman, R. H. (1991). Relationship between organizational justice and organizational citizenship behaviors: Do fairness perceptions influence employee citizenship? Journal of Applied Psychology, 76, $845-855$.

Morgan, G. (1996). Images of organizations. Thousand Oaks, CA: Sage.

Morris, M. W., \& Leung, K. (2000). Justice for all? Progress in research on cultural variation in the psychology of distributive and procedural justice. Applied Psychology: An International Review, 49, 100-132.

Motowidlo, S. J., Borman, W. C., \& Schmit, M. J. (1997). A theory of individual differences in task and contextual performance. Human Performance, 10, 71-83.

Motowidlo, S. J., \& Van Scotter, J. R. (1994). Evidence that task performance should be distinguished from contextual performance. Journal of Applied Psychology, 79, 475-480.

Napier, B. J., \& Ferris, G. R. (1993). Distance in organizations. Human Resource Management Review, 3, 321-351.

Organ, D. W. (1990). The motivational basis of organizational citizenship behavior. In L. L. Cummings \& B. M. Staw (Eds.), Research in organizational behavior (Vol. 12, pp. 43-72). Greenwich, CT: JAI Press.

Pandey, J. (1986). Sociocultural perspectives on ingratiation. Progress in Experimental Personality Research, 14, 205-229.

Parker, C. P., Dipboye, R. L., \& Jackson, S. L. (1995). Perceptions of politics: An investigation of antecedents and consequences. Journal of Management, 21, 891-912.

Pearce, J. (2001). Organization and management in the embrace of government. Mahwah, NJ: Erlbaum.

Pearce, J. L., Bigley, G. A., \& Branyiczki, I. (1998). Procedural justice as modernism: Placing industrial/organizational psychology in context. Applied Psychology: An International Review, 47, 371-396.

Pearce, J. L., Branyiczki, I., \& Bigley, G. A. (2000). Insufficient bureaucracy: Trust and commitment in particularistic organizations. Organization Science, 11, 148-162.

Pfeffer, J. (1992). Managing with power. Boston, MA: Harvard Business School Press.

Pfeffer, J. (1994). Competitive advantage through people: Unleashing the power of the workforce. Boston, MA: Harvard Business School Press.

Podsakoff, P. M., \& MacKenzie, S. B. (1994). An examination of the psychometric properties and nomological validity of some revised and reduced substitutes for leadership scales. Journal of Applied Psychology, 79, 702-713.
Podsakoff, P. M., MacKenzie, S. B., Paine, J. B., \& Bachrach, D. G. (2000). Organizational citizenship behaviors: A critical review of the theoretical and empirical literature and suggestions for future research. Journal of Management, 26, 513-563.

Podsakoff, P. M., Niehoff, B. P., MacKenzie, S. B., \& William, M. L. (1993). Do substitutes for leadership really substitute for leadership? An empirical examination of Kerr and Jermier's situational leadership model. Organizational Behavior and Human Decision Processes, 54, 1-44.

Pugh, D. S., Hickson, D. J., Hinings, C. R., \& Turner, C. (1968). Dimensions of organizational structure. Administrative Science Quarterly, 13, 65-91.

Randall, M. L., Cropanzano, R., Bormann, C. A., \& Birjulin, A. (1999). Organizational politics and organizational support as predictors of work attitudes, job performance, and organizational citizenship behavior. Journal of Organizational Behavior, 20, 159174.

Schminke, M., Ambrose, M. L., \& Cropanzano, R. S. (2000). The effect of organizational structure on perceptions of procedural fairness. Journal of Applied Psychology, 85, 294-304.

Schminke, M., Cropanzano, R., \& Rupp, D. E. (2002). Organization structure and fairness perceptions: The moderating effects of organizational level. Organizational Behavior and Human Decision Processes, 89, 881-905.

Sheppard, B. H., Lewicki, R. J., \& Minton, J. W. (1993). Organizational justice: The research for fairness in the workplace. New York: Lexington Books.

Tsui, A. S., Pearce, J. L., Porter, L. W., \& Tripoli, A. M. (1997). Alternative approaches to the employee-organization relationship: Does investment in employees pay off? Academy of Management Journal, 40, 1089-1121.

Tucker, L. R., \& Lewis, C. (1973). The reliability coefficient for maximum likelihood factor analysis. Psychometrika, 38, 1-10.

Tyler, T. R., \& Lind, E. A. (1992). A relational model of authority in groups. In M. Zanna (Ed.), Advances in experimental social psychology (Vol. 25, pp. 115-191). San Diego: Academic Press.

Valle, M., \& Perrewé, P. L. (2000). Do politics perceptions relate to political behaviors? Test of an implicit assumption and expanded model. Human Relations, 53, 359-386.

Van Scotter, J. R., \& Motowidlo, S. J. (1996). Interpersonal facilitation and job dedication as separate facets of contextual performance. Journal of Applied Psychology, 81, 525-531.

Vigoda, E. (2001). Reactions to organizational politics: A crosscultural examination in Israel and Britain. Human Relations, 54, $1483-1518$.

Wade, R. (1981). The system of administrative and political corruption: Canal irrigation in Southern India. Journal of Development Studies, 18, 287-328.

Weber, M. (1947). The theory of social and economic organization. New York: Free Press.

Witt, L. A., Kacmar, K. M., Carlson, D. S., \& Zivnuska, S. (2002). Interactive effects of personality and organizational politics on contextual performance. Journal of Organizational Behavior, 23, 911-926. 